Diajukan: 01-03-2019 | Revisi: 09-03-2019 | Diterima: 15-04-2019

\title{
Pemberdayaan Karang Taruna di Desa Wonokasian dalam Pengolahan Limbah Plastik Menjadi Sebuah Usaha Ekonomis Produktif
}

\author{
Bayu Hari Prasojo ${ }^{1}$, Rizky Eka Febriansah ${ }^{2}$, Eny Maryanti $^{3}$ \\ Prodi Manajemen, FEB Universitas Muhammadiyah Sidoarjo ${ }^{123}$
}

\begin{abstract}
The purpose of the implementation of the activities of the PKM entitled Empowerment of Karang Taruna of Wonokasian Village in Processing of Plastic Waste into an Economically Productive Endeavour is to empower the sewage treatment of plastic waste which will provide benefits in developing productive economical activities in the form of a business. The problem faced by the partners (Karang Taruna Ndoko and Ngemplak) is that the has not understood the processing of plastic wastes processing into a product worth selling and do not already have one activity that supports efforts to develop economically productive activities. Based on these problems then the two partners agreed to develop economically productive activities in the processing of plastic waste (various product of synthetic flowers, vases and other accessories). Therefore, the steps of implementation is done in this activity are: 1) the training and mentoring of processing waste plastic waste, 2) coaching and mentoring marketing method 3) training and mentoring of the recording of simple accounting. The result of the implementation of these activities is the increased knowledge and skills of the partners in the processing of waste plastic waste, the creation of product Wonokasian, HandCraft mass media publications either online or printed, the presence of offline marketing media and online (instagram, FB, OLX, Tokopedia, and Bukalapak) and a simple accounting and record-keeping system was later expected to be a business of Karang Taruna Wonokasian.
\end{abstract}

Keyword: PKM; empowerment; karang taruna; plastic waste; handcraft kartar; endeavour

\begin{abstract}
Abstrak
Tujuan pelaksanaan kegiatan PKM Pemberdayaan Karang Taruna di Desa Wonokasian dalam Pengolahan Limbah Sampah Plastik menjadi Sebuah Usaha Ekonomis Produktif adalah memberdayakan Karang Taruna dalam pengolahan limbah sampah plastik yang akan memberikan manfaat dalam mengembangkan kegiatan ekonomis produktif dalam bentuk suatu usaha. Permasalahan yang dihadapi mitra Karang Taruna Ndoko dan Karang Taruna Ngemplak adalah mitra belum memahami cara pengolahan limbah sampah plastik menjadi suatu produk yang bernilai jual dan belum mempunyai satu kegiatan yang mendukung upaya untuk mengembangkan kegiatan ekonomis produktif. Berdasarkan permasalahan tersebut maka kedua mitra sepakat untuk mengembangkan kegiatan ekonomis produktif dalam pengolahan limbah sampah plastik (produk aneka bunga, vas bunga dan asesoris lain). Oleh karena itu, metode pelaksanaan yang dilakukan dalam kegiatan ini adalah: 1) Pemberian informasi (sosialisasi) pengolahan limbah sampah plastik, 2) Pelatihan dan pendampingan pengolahan limbah sampah plastik, 3) Pelatihan dan pendampingan metode pemasaran 4) Pelatihan dan pendampingan pencatatan akuntansi sederhana. Hasil dari pelaksanaan kegiatan ini adalah meningkatnya pengetahuan dan keterampilan mitra dalam pengolahan limbah sampah plastik, terciptanya produk HandCraft Kartar Wonokasian, publikasi media massa online maupun cetak, adanya media pemasaran offline (galeri Kartar Wonokasian) maupun online (instagram, FB, OLX, Tokopedia, dan Bukalapak) dan sistem pencatatan akuntansi sederhana serta nantinya diharapkan menjadi sebuah usaha bagi Karang Taruna desa Wonokasian.
\end{abstract}

Kata Kunci: PKM; pemberdayaan; karang taruna; sampah plastik; handcraft kartar; usaha

\section{Pendahuluan}

Mitra PKM merupakan Karang Taruna yang berada di dusun Ndoko dan Ngemplak, desa Wonokasian, Kecamatan Wonoayu, Kabupaten Sidoarjo, suatu desa yang terletak di sebelah barat Kabupaten Sidoarjo dengan jarak sekitar 9,9 km dari Kampus UMSIDA. Desa Wonokasian termasuk dataran rendah dengan luas daerah sekitar 247.550 Ha. Desa Wonokasian terdiri dari 7 dusun yaitu dusun Ndoko, dusun Ngemplak, dusun Nggodek, dusun Lengkong, dusun Kleteh, dusun Kersan dan dusun Kramat. Pada tahun 2016 desa Wonokasian mempunyai jumlah penduduk 5.028 orang yang terdiri dari 2.123 orang laki-laki dan 3.905 orang perempuan dimana kebanyakan diantaranya adalah pemuda. Mata pencaharian utama adalah bertani dan berdagang serta karyawan.

Tingkat pendidikan penduduknya rata-rata masih rendah yaitu lulusan SD dan SMP, namun ada juga yang sudah menempuh pendidikan tinggi, dan di desa Wonokasian ini sudah terbentuk organisasi kepemudaan Karang Taruna yang terdiri dari beberapa Karang Taruna di tingkat dusun, diantaranya adalah

\footnotetext{
${ }^{1}$ bayuhari1@umsida.ac.id
} 
Karang Taruna Ndoko dan Karang Taruna Ngemplak yang memiliki potensi untuk dapat diberdayakan dari segi anggota maupun keaktifannya. Karang Taruna sebagai wadah pembinaan dan pengembangan serta pemberdayaan generasi muda dalam upaya mengembangkan kegiatan pelayanan kesejahteraan sosial dan usaha ekonomis produktif dengan pendayagunaan semua potensi yang tersedia di lingkungan baik sumber daya manusia maupun sumber daya alam yang telah ada. Namun kenyataannya selama ini kegiatan Karang Taruna di desa Wonokasian ini masih sebatas pada kegiatan pelayanan sosial saja, belum menyentuh pada kegiatan usaha ekonomis produktif.

Sementara itu mengacu pada kondisi lingkungan yang ada di desa, dengan bertambahnya jumlah penduduk desa yang merupakan imbas dari mulai banyak bermunculan pabrik di daerah sekitar Desa sehingga memicu pertambahan penduduk dari daerah lain untuk bermukim di desa Wonokasian dan berbagai pembangunan yang ada di desa Wonokasian baik itu minimarket maupun perumahan-perumahan baru, menyisakan satu masalah yaitu sampah, terutama sampah plastik. Warga masih membuang sampah di sembarang tempat (saluran air, pekarangan yang kosong, tepi jalan, dan sungai) sehingga terjadi penyumbatan dan menimbulkan bau busuk.

Menurut Hadi (2014) sampah memiliki potensi yang besar jika dikelola dan diolah. Sehingga dengan memberdayakan potensi yang dimiliki Karang Taruna desa Wonokasian bisa jadi dari limbah sampah plastik ini akan dapat dijadikan suatu kegiatan ekonomis produktif yang selanjutnya dapat diarahkan menjadi sebuah usaha. Untuk memunculkan suatu usaha yang dapat berkelanjutan dibutuhkan banyak perencanaan bisnis yang matang diantaranya berkaitan dengan pencatatan akuntansi dan manajemen keuangan serta manajemen pemasaran. Menurut Hermawan (2014) perencanaan bisnis sangatlah penting agar pelaku usaha memiliki arah dan tujuan kemana bisnis akan dijalankan. Tentunya dengan pelatihan dan pendampingan yang tepat berkaitan dengan pengolahan sampah menjadi suatu produk, pencatatan akuntansi dan manajemen keuangan, serta manajemen pemasaran dari Tim PKM ini kepada mitra Karang Taruna desa Wonokasian nantinya akan dapat memunculkan sebuah usaha ekonomis produktif.

Permasalahan yang dihadapi mitra Karang Taruna desa Wonokasian adalah mitra belum memahami cara pengolahan limbah sampah plastik menjadi suatu produk yang bernilai jual dan belum mempunyai satu kegiatan yang mendukung upaya untuk mengembangkan kegiatan ekonomis produktif. Oleh karena itu tujuan pelaksanaan kegiatan PKM Pemberdayaan Karang Taruna di Desa Wonokasian dalam Pengolahan Limbah Sampah Plastik menjadi Sebuah Usaha Ekonomis Produktif adalah memberdayakan Karang Taruna dalam pengolahan limbah sampah plastik yang akan memberikan manfaat dalam mengembangkan kegiatan ekonomis produktif dalam bentuk suatu usaha.

\section{Materi dan Metode Pelaksanaan}

Metode pelaksanaan yang dilakukan pada kegiatan PKM Pemberdayaan Karang Taruna di Desa Wonokasian dalam Pengolahan Limbah Sampah Plastik menjadi Sebuah Usaha Ekonomis Produktif adalah dengan memberikan informasi, pelatihan dan pendampingan. Adapun tahapan pelaksanaannya adalah sebagai berikut : 1) Pemberian informasi (sosialisasi) mengenai pengolahan limbah sampah plastik menjadi sebuah produk yang mempuyai nilai ekonomis. Tujuan dari tahapan ini adalah mitra mengetahui nilai tambah secara ekonomi dari limbah sampah plastik, sehingga dapat memanfaatkannya, 2) Pelatihan dan pendampingan pengolahan limbah sampah plastik menjadi sebuah produk yang bertujuan memberikan pengetahuan dan keterampilan dalam pengolahan limbah sampah plastik menjadi sebuah produk, 3) Pelatihan dan pendampingan metode pemasaran yang bertujuan memberikan pengetahuan dan keterampilan metode pemasaran secara offline dan online, 4) Pelatihan dan pendampingan pencatatan akuntansi sederhana yang bertujuan memberikan pengetahuan dan keterampilan pencatatan akuntansi sederhana dari sebuah kegiatan ekonomis produktif.

\section{Hasil dan Pembahasan}

Hasil dari beberapa tahapan pelaksanaan pada kegiatan PKM Pemberdayaan Karang Taruna di Desa Wonokasian dalam Pengolahan Limbah Sampah Plastik menjadi Sebuah Usaha Ekonomis Produktif. Hasil pertama, meningkatnya pengetahuan dan keterampilan mitra dalam pengolahan limbah sampah plastik. Sebelum diadakannya kegiatan PKM ini mitra belum mengetahui cara pengolahan limbah sampah plastik. Sementara kondisi lingkungan yang ada di desa, dengan bertambahnya jumlah penduduk desa yang merupakan imbas dari mulai banyak bermunculan pabrik di daerah sekitar Desa sehingga memicu pertambahan penduduk dari daerah lain untuk bermukim di desa Wonokasian dan berbagai pembangunan yang ada di desa Wonokasian baik itu minimarket maupun perumahan-perumahan baru, menyisakan satu masalah yaitu sampah, terutama sampah plastik. Warga masih membuang sampah di sembarang tempat 
(saluran air, pekarangan yang kosong, tepi jalan, dan sungai) sehingga terjadi penyumbatan dan menimbulkan bau busuk.

Oleh karena itu, kegiatan yang dilakukan adalah pemberian informasi (sosialisasi) mengenai pengolahan limbah sampah plastik menjadi sebuah produk yang mempunyai nilai ekonomis. Pemberian informasi ini dilakukan oleh tim PKM baik itu tim dosen dan tim Mahasiswa. Tujuan dari tahapan ini adalah mitra mengetahui nilai tambah secara ekonomi dari limbah sampah plastik, sehingga dapat memanfaatkannya. Menurut Hadi (2014) sampah memiliki potensi yang besar jika dikelola dan diolah. Sehingga dengan memberdayakan potensi yang dimiliki Karang Taruna desa Wonokasian bisa jadi dari limbah sampah plastik ini akan dapat dijadikan suatu kegiatan ekonomis produktif yang selanjutnya dapat diarahkan menjadi sebuah usaha.

Kedua, Terciptanya produk HandCraft Kartar Wonokasian. Setelah mitra mengetahui potensi dari pengolahan limbah sampah plastik yang mempunyai nilai tambah secara ekonomi kemudian dilanjutkan pada tahap pelatihan dan pendampingan pengolahan limbah sampah plastik menjadi sebuah produk yang bertujuan memberikan pengetahuan dan keterampilan dalam pengolahan limbah sampah plastik menjadi sebuah produk. Yang menjadi narasumber dosen dan mahasiswa dari prodi Manajemen Fakultas Ekonomi dan Bisnis Universitas Muhammadiyah Sidoarjo. Pelatihan dan pendampingan ini dilakukan selama tiga bulan dan tiap bulannya dilakukan selama empat kali sehingga total ada duabelas kali, sehingga mitra secara mandiri dapat mengolah limbah sampah plastik menjadi produk HandCraft.

Selama pelaksanaan kegiatan pelatihan dan pendampingan ini banyak sekali temuan yang didapatkan mengenai produk yang nantinya akan dihasilkan, diantaranya yaitu 1) Jenis produk yang akan dibuat sesuaikan dengan tingkat kerumitan, SDM dan waktu yang dibutuhan 2) Nama produk yaitu HandCraft Kartar Wonokasian dan 3) Penentuan harga. Ada beberapa kendala yang dihadapi selama kegiatan PKM ini diantaranya : 1) penggunaan tempat pengolahan limbah sampah plastik di balai desa Wonokasian yang waktunya harus menyesuaikan dengan kegiatan rutin yang telah dilaksanakan di balai desa, 2) frekuensi kehadiran Karang Taruna yang belum maksimal dikarenakan kesibukan dari masingmasing anggota Karang Taruna sebagai pekerja. Namun, beberapa anggota Karang Taruna tetap semangat dan konsisten mengikuti kegiatan ini. Sehingga mitra memperoleh pengetahuan dan keterampilan dalam pengolahan limbah sampah plastik menjadi sebuah produk HandCraft Kartar Wonokasian.

Ketiga, Publikasi media massa online maupun cetak. Kemudian untuk tetap dapat memotivasi mitra dan dapat mempublikasikan kegiatan pemberdayaan Karang Taruna di Desa Wonokasian dalam Pengolahan Limbah Sampah Plastik menjadi Sebuah Usaha Ekonomis Produktif, maka kemudian kegiatan ini dipublikasikan melalui media massa online ${ }^{2}$ dan media cetak harian Surya.

Keempat, Adanya media pemasaran offline maupun online (Instagram, Facebook, OLX, Tokopedia, dan Bukalapak). Setelah mitra mampu membuat produk dari limbah sampah plastik, mitra diberikan Pelatihan dan pendampingan metode pemasaran yang bertujuan memberikan pengetahuan dan keterampilan metode pemasaran secara offline dan online. Pelatihan dan pendampingan ini dilakukan oleh dosen dan mahasiswa prodi Manajemen konsentrasi Pemasaran Fakultas Ekonomi dan Bisnis Universitas Muhammadiyah Sidoarjo, yang dilakukan selama empat kali. Untuk memaksimalkan pemasaran tim PKM dan mitra Karang Taruna menyewa sebuah tempat yang strategis untuk dijadikan galeri, tempat untuk mendisplay produk sehingga memudahkan di dalam pemasaran secara offline. Kemudian disempurnakan dengan pemasaran secara online yaitu instagram, Facebook, OLX, Tokopedia, dan Bukalapak. Dengan tujuan memperluas pangsa pasar sehingga menjadi lebih efektif dan modern.

Kelima, Sistem pencatatan akuntansi sederhana. Selanjutnya mitra diberikan pelatihan pencatatan keuangan sederhana suatu usaha oleh dosen akuntansi keuangan untuk mendapatkan pengetahuan dan keterampilan tentang pencatatan akuntansi dan manajemen keuangan sederhana suatu usaha. Agar mitra memiliki kemampuan dalam mengelola keuangan suatu usaha. Keenam, Adanya usaha bagi Karang Taruna desa Wonokasian. Dari keseluruhan kegiatan tim PKM adalah adanya suatu bentuk usaha Karang Taruna yang diberi nama HandCraft Karang Taruna Wonokasian.

\section{Kesimpulan dan Saran}

Kegiatan Pengabdian PKM Pemberdayaan Karang Taruna di Desa Wonokasian dalam Pengolahan Limbah Plastik menjadi Sebuah Usaha Ekonomis Produktif telah dapat dijalankan dengan baik dan tanpa ada halangan yang berarti. Dengan kerjasama tim PKM yang baik dan peran serta aktif dari Karang Taruna desa Wonokasian dalam kegiatan pengabdian ini maka didapatkan hasil yaitu meningkatnya pengetahuan

\footnotetext{
${ }^{2}$ https://umsida.ac.id/proposal-tiga-dosen-keren-feb-umsida-lolos-pendanaan-ristekdikti/ https://pwmu.co/68911/07/07/sampah-botol-dan-gelas-plastik-itu-berubah-menjadi-bunga-nan-cantik/
} 
dan keterampilan mitra dalam pengolahan limbah sampah plastik, terciptanya produk HandCraft Kartar Wonokasian, publikasi media massa online maupun cetak, adanya media pemasaran offline (galeri Kartar Wonokasian) maupun online (instagram, Facebook, OLX, Tokopedia, dan Bukalapak) dan sistem pencatatan akuntansi sederhana serta nantinya diharapkan menjadi sebuah usaha bagi Karang Taruna desa Wonokasian.

\section{Ucapan Terimakasih}

Pada kesempatan ini kami mengucapkan terimakasih yang sebesar-besarnya kepada Bapak Dr. Nyong Eka Teguh Iman Santoso, M.Fil.I. selaku Kepala LPPM UMSIDA. Bapak Dr. Sigit Hermawan, M.Si. selaku dekan Fakultas Ekonomi dan Bisnis UMSIDA. Bapak Bayu Hari Prasojo, S.Si., M.Pd. selaku Ketua tim PKM ini. Bapak Rizky Eka Febriansah, S.MB., M.SM. selaku anggota 1 tim PKM ini. Ibu Eny Maryanti, S.E., M.A. selaku anggota 2 tim PKM ini.Tim Boutique Antique selaku tim Mahasiswa yang membantu pelaksanaan PKM ini. Bapak Kepala Desa Wonokasian, Wonoayu, Sidoarjo. Karang Taruna Desa Wonokasian, Wonoayu, Sidoarjo.

\section{Referensi}

Hadi, Samsun; Waluyo, Lud. 2014. Pengelolaan sampah pupuk organik di Desa Sukomulyo-Kecamatan Pujon-Kabupaten Malang. Usulan program Ipteks bagi Masyarakat: Universitas Muhammadiyah Malang.

Hermawan, Sigit. dkk. 2014. IbM Untuk Kelompok Usaha Batik Ikat Celup Tanggulangin Sidoarjo.

Yulianto, Eko. dkk. 2015. Pemberdayaan karang taruna Desa Asinan dalam mengembangkan potensi wisata Alam Rawa Pening. The $2^{\text {nd }}$ University Reaserch Coloquium: Universitas Muhammadiyah Semarang. 